\title{
Biogeographic Insights in Central American Cycad Biology
}

\author{
Alberto S. Taylor B. ${ }^{1}$, Jody L. Haynes², Dennis W. Stevenson ${ }^{3}$, \\ Gregory Holzman ${ }^{4}$ and Jorge Mendieta ${ }^{1}$ \\ 1 Universidad de Panamá, Departamento de Botánica, \\ 2IUCN/SSC Cycad Specialist Group, \\ ${ }^{3}$ The New York Botanical Garden, \\ ${ }^{4}$ Pacific Cycad Nursery, \\ 1Panamá \\ 2,3,4USA
}

\section{Introduction}

Cycads (Cycadophyta) are dioecious, palm-like, gymnosperm (non-flowering seed plants) trees and shrubs found broadly across the tropical belt of the world (Fig. 1). Cycads are veritable living fossils once thought to date from the Mesozoic as early as 280 million years ago (mya); however, recent reevaluation of the fossil evidence indicates they originated in the upper Paleozoic, more than 300 mya (Pott et al., 2010). They predated, and were contemporaneous with, the dinosaurs and have survived to the present. As a group, the cycads have been systematically restructured, making use of morphological and molecular characters and cladistic analysis (Caputo et al., 2004). Three families are currently considered valid (Cycadaceae, Stangeriaceae, and Zamiaceae), with a world total of about 330 described species (Osborne et al., 2012). Cycas and Zamia are the most widely distributed and researched genera.

Cycads are solely represented in Panama by the genus Zamia, with 16 described species and a new one soon to be described; of these 17 species, 12 are endemic. Although these 17 species are many more than were previously known and/or described by earlier workers (Stevenson, 1993; Schutzman et al., 1998), still many others are likely to be found, especially in the forested areas near the Colombian border. Zamia, the most widely distributed genus of cycads after Cycas (Fig. 2), extends the length of the isthmus, stretching from Darien Province in the east, abutting on Colombia, to Bocas del Toro and Chiriquí provinces in the west, next to the Costa Rican border (Fig. 3). Only the south-central provinces of Herrera and Los Santos lack cycad populations, and this is likely due to habitat destruction (deforestation for agricultural and cattle ranching endeavors) during past centuries, rather than a natural deficiency. Conversely, on the Atlantic slope there are many cycad populations, including Z. pseudoparasitica, the only known obligate gymnosperm epiphyte.

The main objective of this paper is to present data justifying the study of cycads as biogeographical subjects, taking into account their evolutionary antiquity, as well as their 
extinct and extant distribution, general biology, and reproductive strategy. In this context, we present an example of tropical cycad biology, with the Isthmus of Panama as our main biogeographical framework. Much work on the biology and conservation of cycads has been carried out in this region for over 100 years, starting with many of the noteworthy European plant and animal collectors of the 19th century, up to the Panamanian national workers of today. The cycads serve as a living case of the result of island biogeography, with current distribution being limited by both biotic (pollinators, for example) and abiotic (climate, geography/orography, and habitat restrictions) factors.



Fig. 1. World distribution of extant cycads.
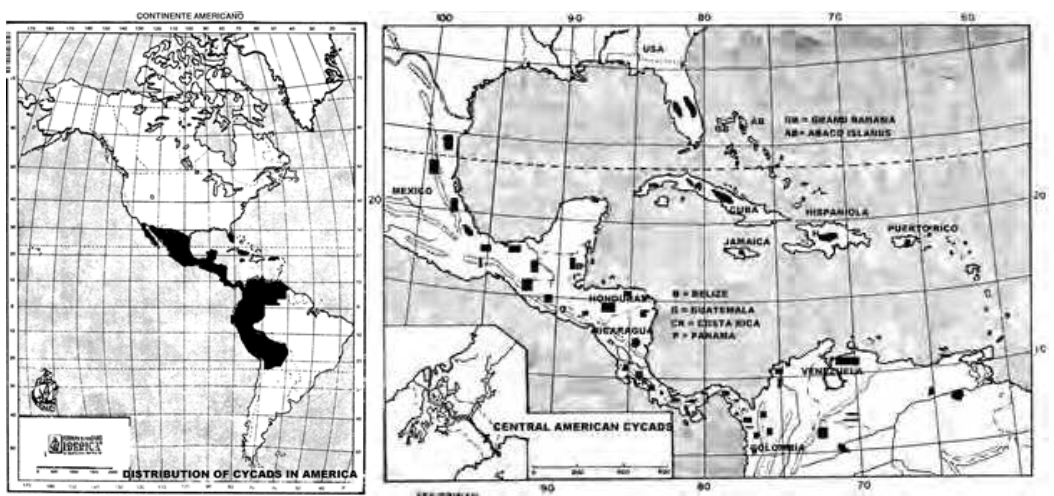

Fig. 2. Distribution of cycads (mostly Zamia) on the North and South American continents and in Central America and the Caribbean.

The Panama Land Bridge-definitely closed about 3-2.7 mya (Coates \& Obando, 1996; Webb, 1997) - served as a physical connection to the northern and southern continents and allowed rapid and almost explosive species radiation. The Isthmus of Panama consists of about 75,500 $\mathrm{km}^{2}$ of land mass (Wikipedia, 2011) and harbors about two-thirds the number of cycad species as Mexico, which is over 20 times larger in area. Panama has almost the 
same number of species as Colombia, which also is nearly 20 times larger. Rising and falling sea levels and the closing of the land bridge made possible the paleontological "Great American Biodiversity Interchange," involving the movement of animals and plants in two directions (north-south and south-north), including cycads from North and South America, into the isthmus (Fig. 4. \& Table 1), where they colonized new habitats and expanded into new niches, giving rise to new species that, together with the existing flora, make this the richest cycad flora per unit area in the neotropics (Stevenson, 1993). Even though only one genus is represented, it is by far the most diverse among the cycads and has the widest distribution after Cycas (Fig. 2).

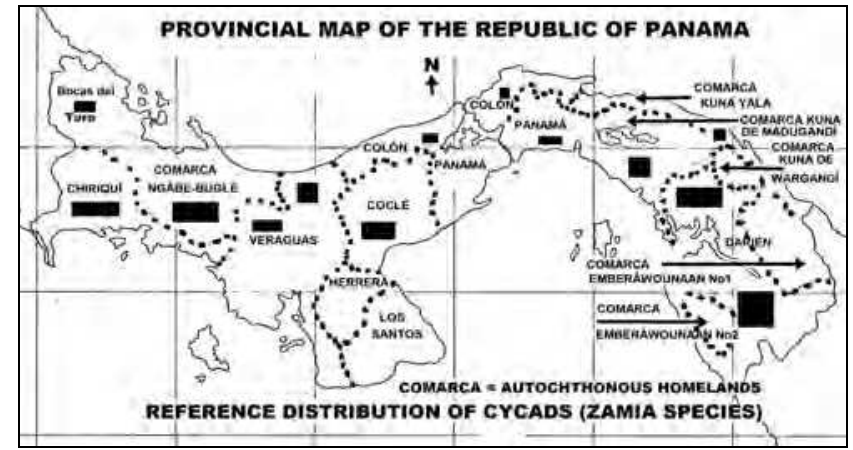

Fig. 3. Generalized distribution of cycads (Zamia) across the Isthmus of Panama.

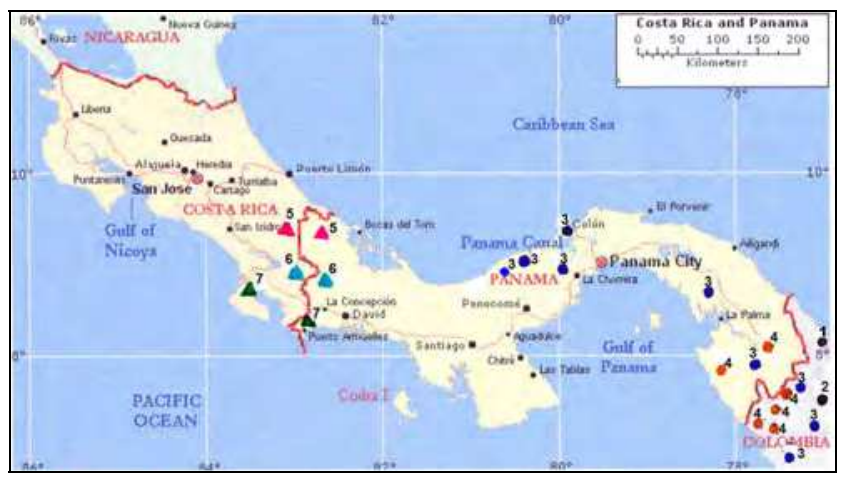

Fig. 4. Interchange of Zamia species on the Isthmus of Panama and new types that evolved there. 1-4. Zamia species from Colombia; 5-7. Zamia species from Central America.

Zamia includes the only known obligate gymnosperm epiphyte (Z. pseudoparasitica). There are types with underground stems (e.g., Z. ipetiensis, Z. cunaria, Z. dressleri) and others with large, above-ground trunks (e.g., Z. elegantissima, Z. nesophila, Z. obliqua); types with leaflets ranging from quite small (Z. acuminata) to very large (e.g., Z. hamannii, Z. imperialis); lowland types sporadically inundated with seawater (Z. nesophila, Z. hamannii) to upland types above 1,500 masl (e.g., Z. lindleyi, Z. pseudomonticola); and types pollinated by only one pollinator (e.g., Pharaxonotha in Z. manicata) to those pollinated by two different genera of pollinators (e.g., Pharaxonotha and Rhopalotria [or Rhopalotria-like weevil] in Z. obliqua and Z. fairchildiana). 


\begin{tabular}{|l|c|c|c|}
\hline \multirow{2}{*}{ CYCAD SPECIES } & \multicolumn{3}{|c|}{ COUNTRY OF ORIGIN } \\
\cline { 2 - 4 } & PANAMA & COSTA RICA & COLOMBIA \\
\hline \hline Z. acuminata* & Yes & Yes & No \\
\hline Z. cunaria & Yes & No & No \\
\hline Z. dressleri & Yes & No & No \\
\hline Z. elegantissima & Yes & No & No \\
\hline Z. fairchildiana & Yes & Yes & No \\
\hline Z. hamannii & Yes & No & No \\
\hline Z. imperialis & Yes & No & No \\
\hline Z. ipetiensis & Yes & No & No \\
\hline Z. lindleyi & Yes & No & Yes \\
\hline Z. manicata & Yes & No & No \\
\hline Z. nesophila & Yes & No & No \\
\hline Z. neurophyllidia & Yes & No & Yes \\
\hline Z. obliqua & Yes & Yes & No \\
\hline Z.pseudomonticola & Yes & No & No \\
\hline Z.pseudoparasitica & Yes & No & No \\
\hline Z. skinneri & Yes & No & No \\
\hline Zamia cf. elegantissima & Yes & & \\
\hline
\end{tabular}

* Considered not synonymous with the described species from Nicaragua.

Table 1. Relationship between the cycad flora of Costa Rica, Panama, and Colombia.

\section{Methods}

More than 40 populations including all 17 species of isthmian cycads were studied between 1998 and 2010. We collected data on plant size and reproductive strategy, including coning cycles, sex ratios, time of dehiscence and receptivity of cones, pollination and pollinators, ripening of seed cones, and disarticulation of cones. Efforts were made to find dispersal agents of cycads, and data on herbivory were collected on almost every visit. Data were also collected pertaining to biogeographic and taxonomic issues of the plicate-leaved species, which have puzzled botanists for more than a century. A concise phylogeny of the genus, distribution among forest types, and conservation threats rounded out the data gathered. Trips were made on foot, by car, by special all-terrain vehicles, by train, boat, and plane, and even on horseback. Different detection methods for pollinating beetles were employed, including exclusion experiments, the use of greased microscope slides tied to petioles near pollen and ovulate cones, and baiting pollinators outside of the normal coning period using dehiscing cones from garden plants.

\subsection{Study area}

The Isthmus of Panama occurs in the tropics of the western hemisphere with the following coordinates: $7^{\circ} 12^{\prime} 07^{\prime \prime}$ to $9^{\circ} 38^{\prime} 46^{\prime \prime}$ North and $77^{\circ} 09^{\prime} 24^{\prime \prime}$ to $83^{\circ} 03^{\prime} 07^{\prime \prime}$ West. It is limited to the west by Costa Rica, to the north by the Caribbean Sea, to the east by Colombia, and to the south by the Pacific Ocean. The isthmus emerged through volcanic activities and elevation of the sea floor (Coates, 2003), and is presently traversed by two cordilleras: one extending 
from Nicaragua to the western side of the canal (the Talamanca range), and the other from the east side of the canal into Colombia (which is related to the Andean system of South America; Wikipedia, 2012). The result is a typically montane and irregular topography with peaks to 3,300 masl. Moreover, there are narrow coastal plains and, in certain zones, contracted alluvial terraces. The cordillera rocks are volcanic in origin. In the central part of the isthmus where the Panama Canal is found, the topography is sinuous, being formed by rocks from the rising sea beds (Instituto Geográfico Nacional Tommy Guardia, 2007).

Because of its geography, Panama has a typical tropical climate. Average temperature is $21.0^{\circ} \mathrm{C}$ at the lowest and $34.5^{\circ} \mathrm{C}$ at the highest, with an annual average of $27.7^{\circ} \mathrm{C}$. April has the highest temperature readings, and the lowest are found in December and March. Rainfall varies according to region, with values from 1,000-7,000 $\mathrm{mm}$ annually, and there are two distinct seasons: a rainy season from the end of April until November, and a dry season from December to April. Panama's rainfall pattern is governed by the seasonal displacement of tropical Pacific air pockets and subtropical ones of the Atlantic and is modified by local orography, although there is a fairly uniform pattern of rainfall distribution throughout the year on the Caribbean slope (ANAM, 2006).

Climatic conditions in Panama are adequate for forest development. However, at present only $44 \%$ of the surface has a natural forest covering. Deforested sites are being used for agriculture and cattle ranching (ANAM, 2006). Extant forests are found north and east in Panama, and the process of forest destruction began with the arrival of the first settlers and has henceforth continued. At present, the continued destruction of natural forests is due to the advancing agricultural and cattle ranching frontier in different regions and to the development of surface mining activity (ANAM, 2006).

\subsection{Forest types \& cycad populations}

During the Great American Biodiversity Interchange, a great many species of plants migrated across the isthmus, some of which have become adapted to the local climate, forming the structure of the natural vegetation observed today. In the case of forests, species biodiversity is from different sources. High-altitude forests have Mesoamerican influence, while in the lowlands, conditions have been influenced by neotropical species and migration from the Chocó region (Louis Berger Group, 2003). The differences between lowland vegetation and those from the highlands are due principally to temperature changes concordant with changes in altitude.

Panamanian cycads are associated with different forest types, and can be found alongside natural montane vegetation and with localized forests in the lowlands. Moreover, it is possible to find cycads in association with human-altered forests. In general, Panamanian cycads grow in three general types of forests: lowland evergreen forest, lowland semideciduous forest, and submontane evergreen forest (although the geographic distribution of most species coincides with the lowland forest types) (Fig. 5, Table 2).

Lowland evergreen forests: These are found below 700 masl; annual rainfall is above 3,000 $\mathrm{mm}$, and temperature varies between $24-30^{\circ} \mathrm{C}$. Tree tops bear leaves year-round, which leads to the understory being relatively sparse. These forests have densities of around 600 individual trees per hectare, representing approximately 100 distinct species (Mendieta, unpubl.). Thirteen species of native cycads are found here, representing $76 \%$ of described isthmian species (Fig. 5, Table 2). 


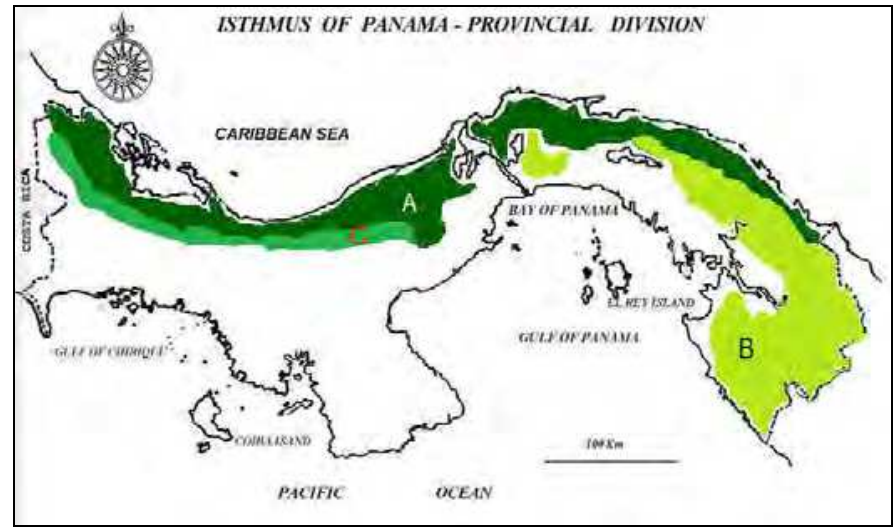

Fig. 5. Distribution of isthmian cycads according to forest type. A. Lowland evergreen forest; B. Lowland semideciduous forest; C. Submontane evergreen forest.

\begin{tabular}{|c|c|c|c|}
\hline Species & $\begin{array}{c}\text { Lowland evergreen } \\
\text { forest }\end{array}$ & $\begin{array}{c}\text { Evergreen } \\
\text { submontane forests } \\
\end{array}$ & $\begin{array}{c}\text { Lowland } \\
\text { semideciduous forests } \\
\end{array}$ \\
\hline Z. acuminata & $x$ & & \\
\hline Z. cunaria & $X$ & & \\
\hline Z. dressleri & $X$ & & \\
\hline Z. elegantissima & $X$ & & \\
\hline Z. fairchildiana & $X$ & & \\
\hline Z. hamannii & $X$ & & \\
\hline Z. imperialis & $X$ & & \\
\hline Z. ipetiensis & $X$ & & $X$ \\
\hline Z. lindleyi & & $X$ & \\
\hline Z. manicata & $X$ & & \\
\hline Z. obliqua & $X$ & & $x$ \\
\hline Z. pseudomonticola & & $x$ & \\
\hline Z. pseudoparasitica & & $X$ & \\
\hline Z. nesophila & $X$ & & \\
\hline Z. neurophyllidia & $X$ & & \\
\hline Z. skinneri & $x$ & & \\
\hline Z. cf. elegantissima & & & $X$ \\
\hline Totals & 13 & 3 & 3 \\
\hline
\end{tabular}

Table 2. Presence of isthmian cycads in natural forest types.

Lowland semideciduous forests. These are found below 700 masl, with annual rainfall between 2,000-3,000 mm, and with temperatures ranging between $24-30^{\circ} \mathrm{C}$. Under these conditions, $30-$ $40 \%$ of tree species are deciduous, and understory species are generally evergreen year round. Tree densities are on the order of 430 individual trees per hectare, representing approximately 100 distinct species (Mendieta, unpubl.). Three native cycad species are found in this forest type, representing $17 \%$ of described isthmian species (Fig. 5, Table 2). 
Submontane evergreen forests. These are found between 700-1,200 masl, with annual rainfall above 3,000 $\mathrm{mm}$. Altitude modifies these forests, so the temperature varies between $21-24^{\circ} \mathrm{C}$ during the year. Tree tops are evergreen year round. Tree densities are on the order of 700 individual trees per hectare, representing 110 distinct species (Louis Berger Group, 2000). Three native cycad species are found in this forest type, representing $17 \%$ of described isthmian species (Fig. 5, Table 2).

\section{Isthmian cycad flora}

Cycads abound throughout the neotropics and even in warm temperate areas of the globe, but they are much more abundant in tropical and subtropical sites with high humidity and temperatures (Fig. 1). Considering its relatively small size and abundance of cycad species, the Isthmus of Panama is an ideal locale for their study, and cycad populations across the isthmus have been examined by the authors over the past three decades. The following is a brief summary of the Panamanian cycad flora:

1. Zamia cunaria (Fig. 6A) - a plant with no above-ground stem and with very few leaves in mature specimens; its habit and morphology are similar to that of Z. ipetiensis; it is a narrow Panamanian endemic, found only along a road encompassing national land and part of the Kuna or Dule homeland in eastern Panama, where it grows at 400-650 masl.

2. Z. dressleri (Fig. 6B) - another species with no above-ground stem and with very few leaves in mature specimens (1-3 generally). This is a Panamanian endemic found on the Atlantic side of the isthmus in Colón Province. It is very hardy and will withstand rough handling, drought, and some direct sunlight.

3. Z. obliqua (Fig. 6C) - a shrub to large tree with distinctive leaflets indicative of its specific epithet, although there are variations on the theme; it is found in separate sites in Darién Province, and there are disjunct, remnant populations abutting on the Atlantic coast, near the Panama Canal area, and in northwestern Panamá Province, growing in extended sympatric association with Z. imperialis and Z. pseudoparasitica in north-central Panama. It almost rivals Z. pseudoparasitica in distribution and is the only widely-disjunct cycad in Panama.

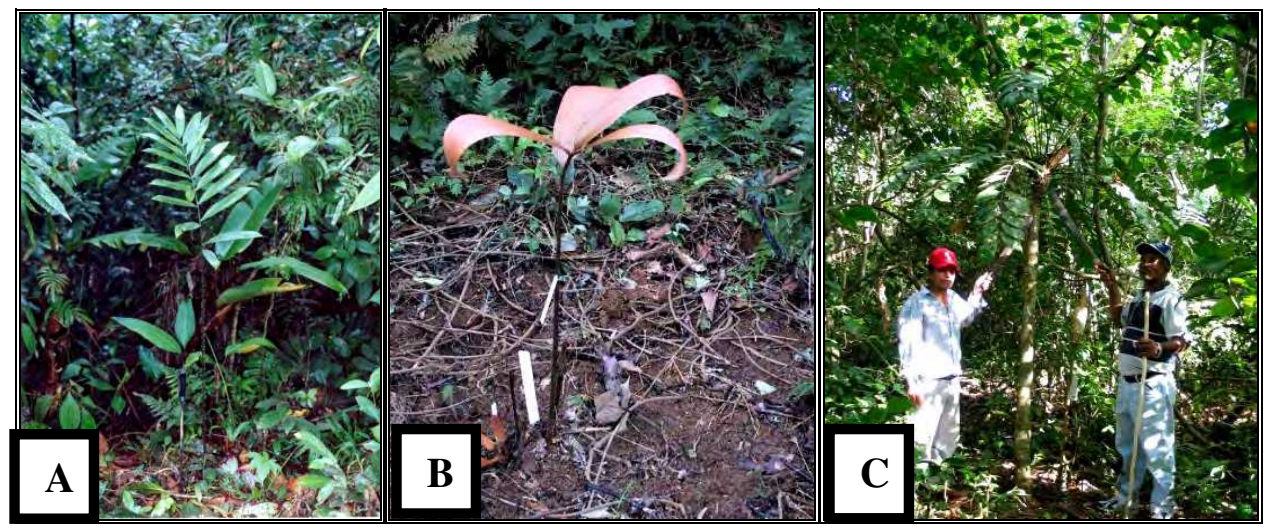

Fig. 6. Biodiversity of Panamanian cycads. A. Zamia cunaria, with underground stem; B. Z. dressleri, idem, with pollen cones near soil level; C. Z. obliqua with huge, arborescent trunk. 
4. Z. pseudoparasitica (Fig. 7A) - this obligate tree-dwelling cycad, while a Panamanian endemic, is perhaps the widest ranging species in Panama, being found on high, and sometimes lower, tree branches from Bocas del Toro Province in the west to Colón Province near the northern end of the Panama Canal; germinated seeds have been found on the ground, but these apparently are eaten by unknown animals, and neither juvenile nor adult plants are ever seen growing terrestrially.

5. Z. acuminata (Fig. 7B) - a plant with no above-ground stem in habitat (potted plants may show aboveground stems). It is found above 500 masl in east-central Coclé Province. This species is small, with many long-acuminate leaves; it has been treated as synonymous with another plant along the Río San Juan in southern Nicaragua, but it likely is a different species (Schutzman, 2004; Lindström, pers. comm.). The longacuminate leaves are distinctive in the genus.

6. Z. imperialis (Fig. 7C-D) - previously known as the "red leaf skinneri," it is quite attractive with crimson-colored leaves seen all over the forest when the leaves are emerging. The plants are generally short-stemmed with a few large leaves (1-3 generally) and huge leaflets. It is an endemic species of the central Atlantic versant.

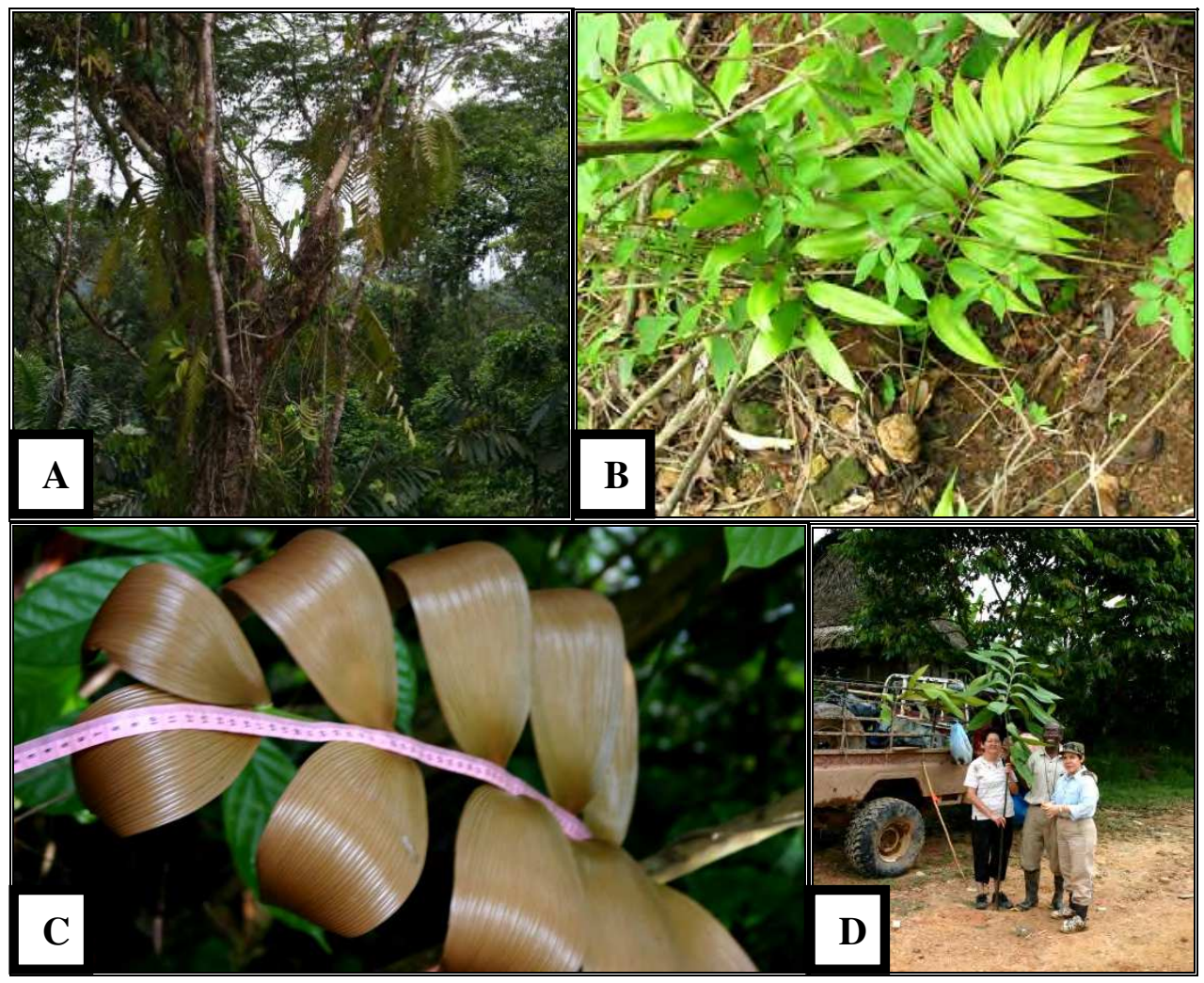

Fig. 7. Biodiversity of Panamanian cycads (cont'd.): A. Specimens of Zamia pseudoparasitica hanging from tree branches in north-central Panama; B. Z. acuminata, a small-leaved species with underground stems; C-D. Z. imperialis, one of the large-leafleted, plicate-leaved species. 
7. Z. hamannii (Fig. 8A) - a shrubby to large, arborescent, island-dwelling plant that often grows near the sea in Bocas del Toro Province. Emergent leaves are rosy red to orange. This species is similar to Z. imperialis in overall appearance, but has a silver tomentum on emerging leaves, bears many more leaves, and has different seed cones.

8. Z. nesophila (Fig. 8B) - shrubby to arborescent, with leaves green (emergent and mature) and leaflets and cones differing from those of other plicate-leaved species. It is found near beaches, withstanding sea spray and occasional inundation by seawater. Like $Z$. hamannii, it is an island-dweller in the Bocas del Toro region.

9. Z. skinneri - long confused with other plicate-leaved taxa but recently recharacterized (Taylor et al., 2008; 2012), it grows large, arborescent trunks, bears green-emergent leaves, and is widely distributed throughout coastal mainland Bocas del Toro Province.

10. Z. neurophyllidia - similar to Z. skinneri (and similarly confused for many years), but much smaller and with a different form of seed cone. It is distributed in extreme northwestern Panama and may occur in Costa Rica.

11. Z. elegantissima - a small shrub to very large tree (Fig. 8C), it is found near eastern and northern Colón Province on the Atlantic versant and is sympatric with Z. cunaria, where it grows a stem to almost $3 \mathrm{~m}$ high. Populations are very small, numbering less than 50 plants, and emergent leaves are cream-colored.

12. Z. cf. elegantissima - known among cycad workers as "blanco," or white, because of the snow-white appearance of its new leaves, this species appears to be a diminutive variant of Z. elegantissima. However, this is the only Panamanian species with this type of emergent leaf. The shape and size of the cones and seeds, as well as the overall size and number of leaves, and the diameter and height of the trunks of mature specimens also are smaller in every respect. Reproductive plants range from nearly acaulescent to $1.5 \mathrm{~m}$ high, and this species is endemic to Panamá Province.

13. Z. pseudomonticola - this species is very similar to Z. fairchildiana (see below) and is distributed in far western Panama.

14. Z. fairchildiana - described by Luis Diego Gómez, the same author as Z. pseudomonticola, plants apparently are also found in Costa Rica and are somewhat similar in overall appearance to Z . elegantissima, but the pointed leaflets have a raised surface on the upper or adaxial side; the size and form of cones and the emergent leaves also differ. It is found in western to southwestern Panama.

15. Z. lindleyi - a shrubby to arborescent, narrow-leafleted plant in the high-altitude, humid forests of Chiriquí Province, northwestern Panama (Fig. 8D).

16. Z. ipetiensis - a small to medium-sized plant with branching underground stems and leaves to approximately $1 \mathrm{~m}$ tall (Fig. 8E). It is endemic to eastern Panama in one of the homelands of the Emberá tribal group. This is the only species in Panama in which the pollen cones in natural populations can number up to 13 on an individual plant.

17. Z. manicata - found only in Darién Province, it is the only Panamanian Zamia (and one of only two zamias, the other of which is in Peru) having a petiolule, or leaflet stalk, near the base of which is a small, gland-like protuberance (Fig. 8F-G).

\section{Reproductive biology, sex ratio \& herbivory in isthmian cycads}

\subsection{Reproductive biology}

Most Panamanian cycads in natural populations, when coning, do so only once a year. Four months are required for cone maturation, 1-2 months for pollen dehiscence and receptivity, 

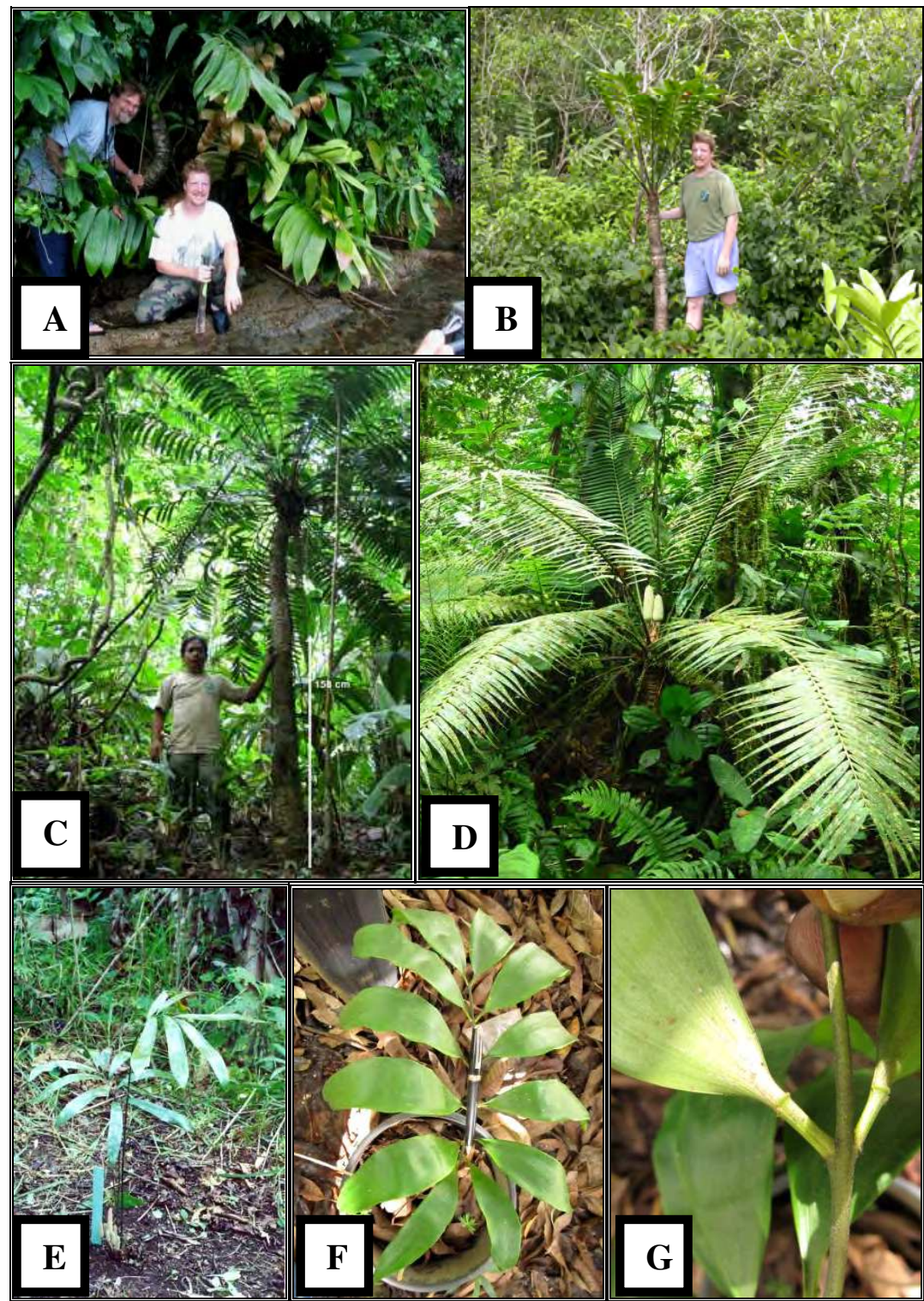

Fig. 8. Biodiversity of Panamanian cycads (cont'd.). A. Zamia hamannii, a species sometimes inundated by seawater; B. Z. nesophila, a species mostly growing on sand and sometimes inundated by seawater; C. Z. elegantissima; D. Z. lindleyi, a high mountain species, with two pollen cones; E. Z. ipetiensis, a species similar to Z. cunaria but which produces many more pollen cones per plant; F-G. Z. manicata, showing the petiolules and associated gland at the base of the leaflets. 
and 1-2 years for seed ripening. There are exceptions (e.g., Zamia acuminata seeds ripen in about eight months after pollination), but this is the general rule for almost all of the populations studied. Outside the natural environment (gardens, landscapes, or isolation due to habitat destruction), coning can occur at any time and sometimes occurs many times during a year. We have not observed any stress-triggered reproduction-coning after disturbance as a do-or-die strategy-in Panamanian Zamia species, although examples of having mature cones many times a year in natural populations have been observed in Z. nesophila in the Bocas del Toro archipelago and in Z. hamannii somewhere far away in the same political jurisdiction. Zamia nesophila has been observed having dehiscing pollen cones and receptive ovulate cones three times during a given year and $Z$. hamannii twice.

The grandfather of cycad studies, Charles Joseph Chamberlain, thought that cycads were wind pollinated just like other gymnosperms, even knowing that insects were found in, upon, and about pollen cones at the time of pollination (Chamberlain, 1919; 1935), and that others (Pearson, 1906; Rattray, 1935) had, indeed, observed beetles on pollen cones and written about the possibility of insect pollination in the South African cycads Encephalartos altensteinii and E. villosus. Pollination by insects is now strongly supported for cycads as a group (Norstog \& Nicholls, 1997; Wilson, 2002; Proches et al., 2009), and pollinators have been found for all populations studied on the Isthmus of Panama with the exception of Zamia neurophyllidia. Pollinators represent weevils that are morphologically similar to Rhopalotria, as well as the erotylid pleasing fungus beetle, Pharaxonotha (Fig. 9D). Pharaxonotha is always found in dehiscing pollen cones and is sometimes accompanied by Rhopalotria, suggesting that Pharaxonotha is the primary pollinator of isthmian zamias. The insects enter the pollen cones and ovulate cones guided by aromatic chemicals emitted by the cones (Stevenson et al., 1998; Taylor, 2002).

The exact form of pollination and the reward offered to pollinators have been variously discussed by others, and Terry et al. (2007) put forth an odor-mediated "push-pull" pollination mechanism in which the volatiles emitted by dehiscing pollen cones and receptive ovulate cones are increased at certain times in a diel cycle. When the dehiscing cone temperature becomes quite high above ambient, the pollinators are "pushed" out of the cone and move toward available receptive ovulate cones. When the temperature is reduced, the volatile concentration also declines, and the insects are once more "pulled" into the pollen cones. In a preliminary experiment accompanied by the senior author in 2006, Terry and Roemer (unpublished) observed only a slight increase in pollen cone temperature above ambient in an excised cone in the lab that was maintained in a water-absorbent material. The extremely rainy period and no available assistance and infrastructure to safeguard the instruments, however, made it impossible to undertake the field experiment; this will be taken up in the future. Suinyuy et al. (2012) have confirmed the relationship between volatile emissions and insect attraction to dehiscent pollen cones and receptive ovulate cones of Encephalartos villosus in South Africa. Thermogenesis exists, but the confirmation of the "push-pull mechanism" of Terry et al. (2007) still remains to be supported in other cycad species, including those of Encephalartos.

Another question to consider is the mutualistic reward offered to the plant by pollinator destruction of pollen cones, which, according to Marler (2010), is not only the conveying of pollen to receptive ovulate cones, but also a cryptic benefit of cone tissue disposal which translates into an increase in ultimate lifetime reproductive effort or events. In fact, any event, natural or accidental, that rapidly disposes of cycad cones in a given reproductive cycle will hasten the onset of the next reproductive cycle. This has been observed by the 
senior author in at least one of the isthmian species (Zamia cf. elegantissima) in which the destruction of an almost mature ovulate cone by larvae of the lepidopteran Eumaeus godarti brought about the onset of a new reproductive cycle in a short time (about a year). When this does not happen, the reproductive cycle takes many years to be repeated in this species. A point should be made here that cone disposal by non-pollinating insects or natural destruction and abscission of pollen cones in isthmian cycads takes place even without the benefit of the pollinators, both in natural populations and in garden-grown plants.

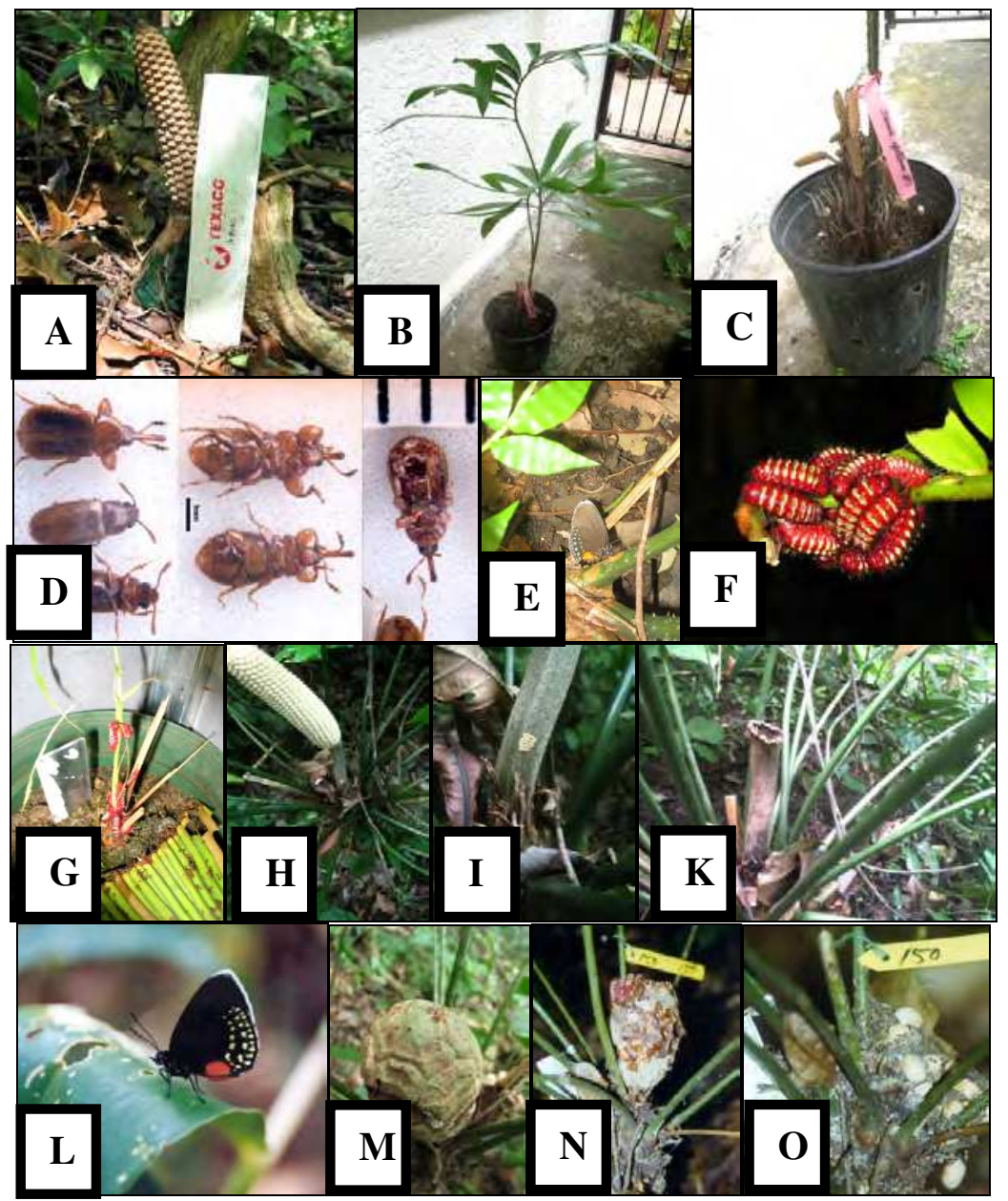

Fig. 9. Pollination and herbivory in Panamanian cycads. A. Pollen bait cone of Zamia cf. elegantissima; B. Small potted pollen plant of Z. ipetiensis used as bait; C. Pollen cones of B; D. Cycad pollinators: Pharaxonotha beetles (left middle and left bottom) and Rhopalotria-like weevils (center and right); E. Eumaeus godarti butterfly laying eggs; F. E. godarti larvae on Z. lindleyi leaf; G. Zamia germling destroyed by E. godarti larvae; H-K. Destruction of Z. elegantissima pollen cones by E. godarti larvae; L. E. godarti mature butterfly; M-O. Attacked seed cone of $Z$. cf. elegantissima with liberation of seeds (these seeds later germinated). 
A method devised by the senior author known as the "pollen bait method" makes use of ex situ dehiscing pollen cones of the same or related species taken to a natural population, with the pollen cone peduncle in a water-absorbent material and held in an appropriate receptacle (Fig. 9A). Small potted plants with dehiscing pollen were also used (Fig. 9B-C). After two days, the bait cone is retrieved and, if it was effective (bait cones of the same species are always effective), pollinators (weevils and/or beetles) are captured even outside of the normal coning period for the species. This, of course, means that the pollinators in some form (perhaps as dormant pupae) are present in the populations and are always ready for a dehiscent or receptive cone. Because cones of different species have been effectively used as bait, it follows that some pollinators are either not speciesspecific or different cycad species emit the same or similar aromatic attractants. This interspecific attraction is not found in all isthmian species. Pollinators are found in large numbers throughout the Isthmus of Panama. However, because the same insect species sometimes pollinates different cycad species, and different pollinators can pollinate the same species, it appears to be relatively easy for isthmian cycads to extend their ranges. This probably explains the broad distribution of Zamia obliqua and Z. pseudoparasitica across the isthmus.

\subsection{Coning cycle \& sex ratio}

Timing of coning is different for the various species of Zamia in Panama; in most populations, individuals do not cone every year, or those that do generally represent a small percentage of the total population (Table 3). However, in the case of Z. ipetiensis and two populations of $Z$. cunaria, most individuals that appeared mature, judging from leaf size, bore cones. In populations of other species (e.g., Z. cf. elegantissima), most individuals observed in the population studied bore cones, but in one coning cycle (year 2000) most plants did not cone. One must consider that ovulate plants use more resources in cone building than pollen plants. While most species appear to have a nearly 1:1 sex ratio, the ratio may vary markedly from one coning cycle to the next. In the case of Z. ipetiensis, it is almost certain that there is a bias toward ovulate plants. Pollen plants, however, produce many more cones per plant (up to 13) than other species, and this apparently results in the population being quite vigorous, for there is always enough pollen during a coning cycle to account for the greater number of ovulate plants.

\subsection{Herbivory}

Eumaeus godarti (Lepidoptera: Lycaenidae) (Figs. 9E \& L) is the principal cycad herbivore in Panama, but only in a very small number of cases has it adversely affected the populations infested, and most plants recover rapidly after being attacked. The life cycle of the insect has been worked out by the senior author for isthmian populations. Even in cases in which the larvae of the butterfly eat most of the mature ovulate cone parenchyma, the seeds are left intact, and these germinate sooner than if the cone is left to disintegrate naturally (Fig. 9M-O). In this case, the herbivore can be considered an opportunistic semimutualist Zamia symbiont, at least part of the time (Taylor, 1999), and an aid to limited seed dispersal, especially if seed cleaning occurs on plants near natural embankments or cliffs. 


\begin{tabular}{|c|c|c|c|c|c|c|}
\hline \multirow{2}{*}{$\begin{array}{l}\text { Species } \\
\& \text { Year }\end{array}$} & \multirow{2}{*}{$\begin{array}{l}\text { Pop. Size } \\
\text { (approx.) }\end{array}$} & \multirow{2}{*}{$\begin{array}{c}\text { Plants } \\
\text { Observed }\end{array}$} & \multicolumn{2}{|c|}{ \# Coning } & \multirow[b]{2}{*}{$\%$ Coning } & \multirow{2}{*}{  } \\
\hline & & & q & $\hat{0}$ & & \\
\hline $\begin{array}{l}\text { Z. acuminata } \\
\text { 1999-2002 }\end{array}$ & $>400$ & 170 & 65 & 73 & 81.2 & 0.9 \\
\hline $\begin{array}{l}\text { Z. acuminata } \\
2002\end{array}$ & $>400$ & 170 & 24 & 22 & 27.0 & 1.1 \\
\hline $\begin{array}{l}\text { Z. cunaria } \\
2007\end{array}$ & $>100$ & 31 & 3 & 5 & 25.8 & 0.6 \\
\hline $\begin{array}{l}\text { Z. cunaria } \\
2007\end{array}$ & $>100$ & 28 & 14 & 2 & 57.1 & 7.0 \\
\hline $\begin{array}{l}\text { Z. cunaria } \\
2008\end{array}$ & $>100$ & 36 & 32 & 3 & 97.2 & 10.7 \\
\hline $\begin{array}{l}\text { Z. cf. elegantissima } \\
1998-2000\end{array}$ & $>100$ & 60 & 3 & 14 & 28.3 & 0.2 \\
\hline $\begin{array}{l}\text { Z. cf. elegantissima } \\
1999\end{array}$ & $>300$ & 223 & 9 & 17 & 11.7 & 0.5 \\
\hline $\begin{array}{c}\text { Z. cf. elegantissima } \\
\text { 1999-2001 }\end{array}$ & $>300$ & 223 & 57 & 42 & 44.4 & 1.4 \\
\hline $\begin{array}{l}\text { Z. cf. elegantissima } \\
\text { 2000-2001 }\end{array}$ & $>700$ & 362 & $32 *$ & $61^{* *}$ & 25.7 & 0.52 \\
\hline $\begin{array}{c}\text { Z. cf. elegantissima } \\
\text { 1999-2001 }\end{array}$ & $>700$ & 362 & 90 & 110 & 55.2 & 0.8 \\
\hline $\begin{array}{l}\text { Z. ipetiensis } \\
1999-2001\end{array}$ & $>300$ & 150 & 75 & 29 & 69.3 & 2.6 \\
\hline $\begin{array}{l}\text { Z. ipetiensis } \\
2000\end{array}$ & $>300$ & 55 & 33 & 21 & 98.2 & 1.6 \\
\hline
\end{tabular}

Table 3. Coning events in Panamanian cycads during different coning cycles. ( ${ }^{*}$ Plants that had coned the year before were still bearing old cones [19]; ** some of these [24] had also coned the year before).

\section{Dispersal of isthmian cycads}

Cycad seeds are formed by two layers: an outer pulpy layer known as the sarcotesta - which harbors toxins in some cycads and is attractive to many biotic dispersers (Fig.10A-B) - and an inner hard layer known as the sclerotesta (Fig. 10C). Cycad seeds range from relatively large to relatively small, according to species (Fig. 10), varying in isthmian species from 2.8$3.0 \mathrm{~cm}$ long and 1.6-1.8 $\mathrm{cm}$ wide in Zamia elegantissima (on the large side), to $1-1.5 \mathrm{~cm}$ long and $0.5-0.8 \mathrm{~cm}$ wide in Z. manicata (medium-sized), down to $1.6-1.9 \mathrm{~cm}$ long and $0.4-0.5 \mathrm{~cm}$ wide in Z. acuminata (the smallest). Most cycad seeds require an after-ripening period, after seed cone disarticulation, to germinate. This period can range from a few weeks, as in most Zamia species - including those from Panama - to more than a year, as in some Encephalartos species in South Africa. In a year-long experiment at the University of Panama (unpublished), the germination rates for Z. cf. elegantissima, Z. acuminata, and Z. ipetiensis seeds decreased during the year, and germination was negligible after that. 


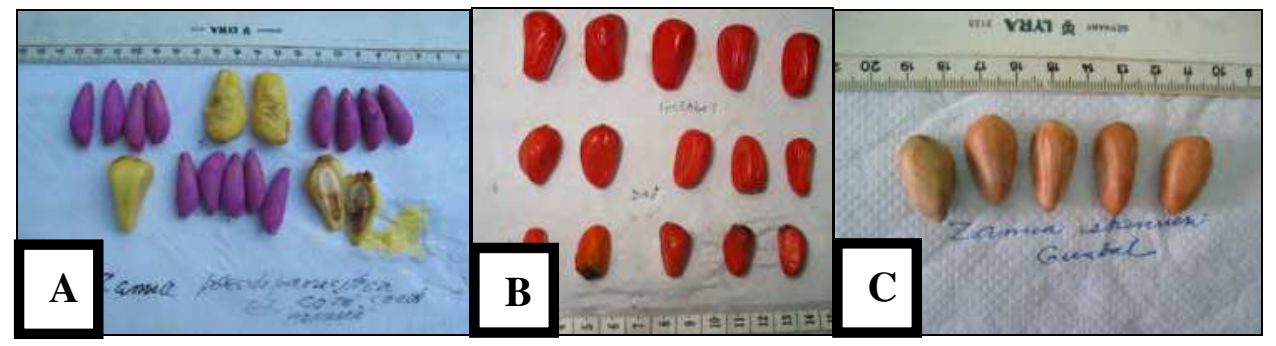

Fig. 10. Istmian cycad seeds. A. Zamia pseudoparasitica with yellow sarcotesta (violet color is due to antifungal solution on the sclerotesta); B. Z. imperialis (above) and Z. nesophila (below) with red sarcotesta; C. Z. imperialis, showing the stony sclerotesta.

Palatability of the sarcotesta is known for many cycad species (Norstog \& Nicholls, 1997; Jones, 2002), and this should also stand for isthmian species such as Zamia pseudoparasitica, the sarcotesta of which exudes a gummy substance when ripe (Fig.10A). The sarcotesta of all isthmian species is red, except for that of Z. pseudoparasitica, which is yellow. It generally becomes soft and quite pulpy during after-ripening. At the moment, there are no known long-distance dispersal agents for any cycad species in Panama, except gravity when seeds fall near cliff sides or on the sides of steep hills. Ants and other insects and also crabs have been seen moving seeds over short distances. Perhaps the animals that dispersed seeds no longer exist, or perhaps there has just not been enough monitoring time or effort put into studying and discovering the dispersers. In the case of Z. pseudoparasitica, bats and toucans have been reported by a few of our field supporters in western Panama to transport seeds, but definitive proof is still needed. Two of us have seen the toucans flying in the area where the species is growing, and there are bats in the area and lots of anecdotal statements, but no real proof-although the seeds have been seen germinating on the branches of different trees not containing cycads, and the most likely dispersers would be birds, bats, or mammals. Traps with mature seeds were set in preliminary trials and will be repeated, because of both negative results and the field observance of the senior author and one of his field assistants of the overnight consumption of one third of a mature Z. pseudoparasitica cone in north-central Panama in an area with toucans and bats.

Janzen (1981a; 1981b), in his seminal studies of the guanacaste tree in neighboring Costa Rica (Enterolobium ciclocarpum: Mimosoideae), hypothesized that equids the size of contemporary Costa Rican range horses were present in Costa Rica in the late Pleistocene. Removed by evolutionary forces for about $10^{6}$ years, they were again introduced as modern horses (Equus caballus) by the Spaniards after the European colonization of the Americas. Examples of these horses are Costa Rican free ranging horses that eat and then excrete the gunacaste (also known as Corotu or curutu in Panama) seeds in their dung, with most of these germinating later. The equids, then, are the ideal dispersors of the tree, although they were absent for so many thousand years. Other approaches to this problem of apparent missing dispersers (Hunter, 1989) consider that no animal interaction is necessary to explain the spread and germination of E. ciclocarpum seed, and that hidrochory (dissemination by water) is suggested as the preferred dispersal strategy. In the case of cycad seeds, their toxicity and knowing that almost all with viable embryos sink in water, hydrochory (except in known cases of a few Cycas species, such as C. litoralis, C. micronesica, and C. rumphii) is ruled out in most cases, and dispersal by animals 
has been reported as actually being oberserved in many cycads in Africa, Southeast Asia, and Australia, but very little information has been given for American cycads (Jones, 2002).

There are anecdotal reports of human consumption of cycad seeds in the aboriginal region of eastern Panama (Taylor, 2012), and there is a first report of the pre-Columbian use of Zamia starch grains on cutting utensils in an unknown aboriginal group in western Panama during preceramic times (Dickau, 2007). But in none of these cases is there irrefutable evidence of human beings as actual dispersers of the species. At present, the aboriginal groups that make use of these plants usually take the parts needed from the wild. In eastern Panama, however, we have seen a few plants that have been sown around the Embera village, but still near the original natural population of Z. ipetiensis.

\section{6. "Island" biogeography \& isthmian cycads}

As mentioned above, the immigration of cycads from North and South America into the newly forming isthmus and subsequent speciation events - which have occurred from late Pliocene to recent geologic time-account for most of the cycad species on the isthmus based on congruence of observed patterns of phylogenetic relationships combined with the current geographical distribution of species (Caputo et al., 2004). Conversely, the plicateleaved zamias of northwestern Panama-specifically those in the Bocas del Toro regionmay have originated on an ecological time scale, and the current distribution of this unique assemblage may best be explained by a modification of the "dynamic habitat" hypothesis of Gregory and Chemnick (2004), which states that Dioon populations in Mexico migrated up and down in elevation, and north and south, in response to warming and cooling climatic cycles corresponding to glaciation events (see Taylor et al., 2008).

\subsection{The plicate-leaved zamias \& their distributions}

The plicate-leaved zamias are distributed from western Central America into northern South America. There is evidence that leaflet "plication" evolved independently within the genus, and that the South American plicate-leaved taxa (e.g., Zamia roezlii and Z. wallisii) are phylogenetically unrelated to those in Central America (Caputo et al., 2004). The Central American representatives are largely restricted to the Atlantic slope of the continental divide and include Z. dressleri, Z. hamannii, Z. imperialis, Z. nesophila, Z. neurophyllidia, and Z. skinneri in Panama (the latter two may also occur in coastal southeastern and south-central Costa Rica, respectively), as well as one or more undescribed species in Costa Rica and southern Nicaragua. All of the named species, except Z. dressleri, occur in the Bocas del Toro region, with at least three of these species -Z. hamannii, Z. imperialis, and Z. nesophila-being Panamanian endemics (Taylor et al., 2008).

\subsection{Evolutionary hypothesis}

The Bocas del Toro region of northwestern Panama was a site of intense volcanic activity from about 20 mya to less than 2.8 mya when the final closure of the isthmus took place (Coates et al., 2005; Fig. 11). During this period, there was ample time for the immigration of plant and animal species from the northern and southern continents into the isthmus. Sea level rise and continental submergence over the past few thousand years have created numerous islands and peninsulas in the Bocas del Toro region (Anderson \& Handley, 2002) 
and have resulted in marked morphological differentiation in insular mammals (Anderson \& Handley, 2001; 2002) and plants (Taylor et al., 2008) compared to their mainland counterparts. Surprisingly, the processes that have led to this striking level of divergence may have occurred in as little as 5,000-10,000 years, according to recent estimates of the ages of the islands in this region (Anderson \& Handley, 2002).

Taylor et al. (2008) hypothesized an explanation for the biogeographical and evolutionary patterns of the plicate-leaved zamias of northwestern Panama in their "dynamic habitat" hypothesis, which is similar to that proposed by Gregory and Chemnick (2004) for the Mexican species of Dioon. In Mexico, movement to higher elevations during inter-glacial periods resulted in colonization of new river valleys by Dioon, followed by secondary isolation within and between river drainages and subsequent rapid vicariance of the majority of extant species. During ice age phases, however, populations are forced downslope and southward, possibly resulting in genetic remixing. These processes have, then, been repeated numerous times over the past two million years (Gregory \& Chemnick, 2004).

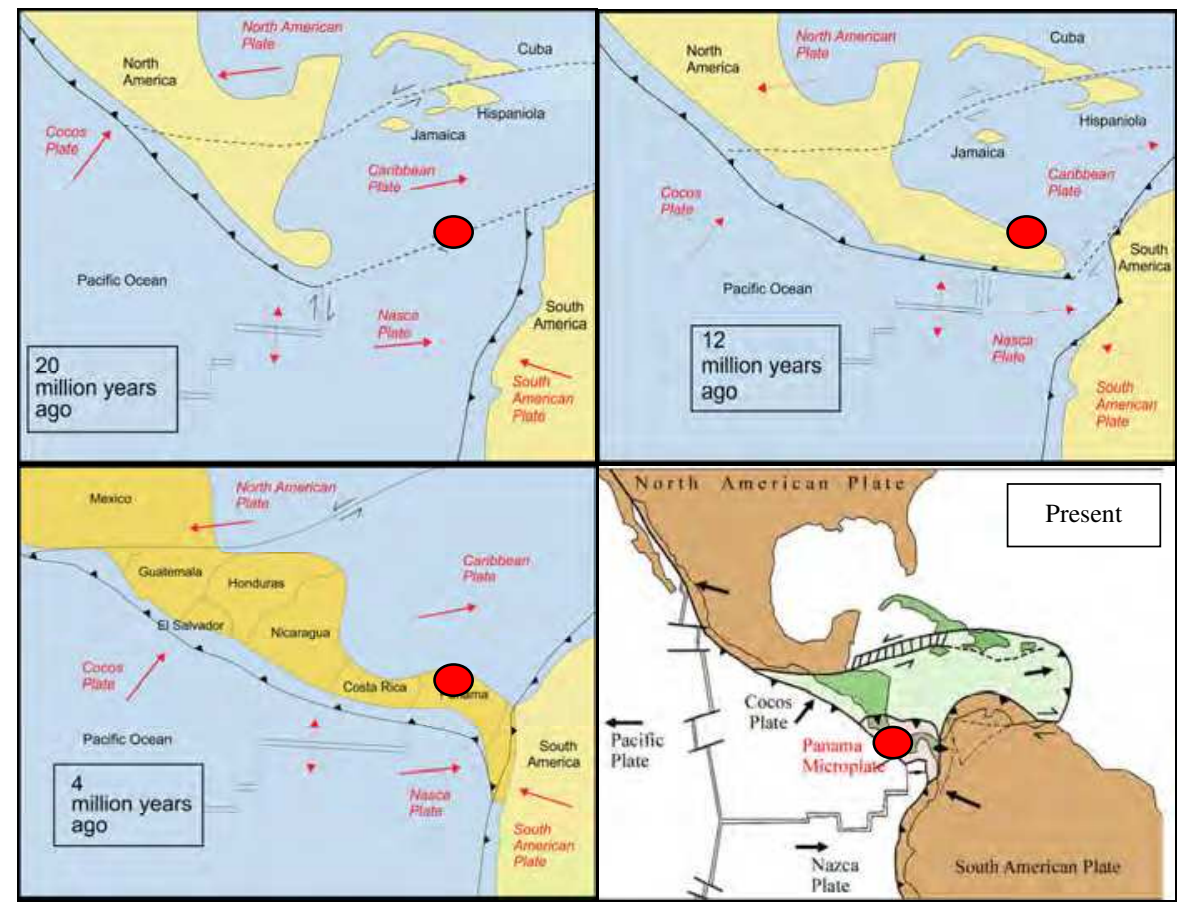

Fig. 11. Timeline of formation of the Isthmus of Panama. Maps kindly donated by Dr. Anthony Coates of the Smithsonian Tropical Research Institute (STRI) in Panama City. (The red dot indicates the approximate location of the Bocas del Toro region of Panama.)

The primary difference between Gregory and Chemnick's (2004) hypothesis and that proposed by Taylor et al. (2008) for the plicate-leaved zamias of Bocas del Toro is that, rather than (or in addition to) temperature fluctuations being the primary driving factor, the current distribution of taxa is primarily due to the periodic rise and fall of sea levels that accompanied the dramatic 
Pleistocene changes in climate. Higher sea levels during warmer inter-glacial periods created geographical barriers that isolated cycad populations and allowed them to evolve independently, whereas lowered sea levels during the periodic ice ages allowed for renewed genetic interchange and introgression as populations merged back together into newly exposed land areas. This sea-level change cycle has been repeated several times, following each ice age, resulting in relatively brief but intense periods of isolation.

Following this logic, isolation onto separate islands combined with unique environmental pressures associated with an insular existence likely contributed to allopatric speciation of Zamia hamannii and Z. nesophila from their mainland counterparts, possibly over just the past $5,000-10,000$ years. Similar evolutionary processes likely played a role in the vicariance of $Z$. imperialis and Z. neurophyllidia, except that instead of being restricted to different islands, the propensity of these latter species to grow inland away from the coast was likely an important factor in maintaining their isolation from populations nearer the coast, thus allowing for their independent evolutionary pathways (Taylor et al., 2008). Because the isolation processes have occurred several times in the past million years, genetic evidence will be needed to distinguish the most recent event from previous sea-level increases.

As Taylor et al. (2008) suggested, Zamia skinneri is unique within this species complex with regard to its biogeographical and evolutionary patterns because it is widespread throughout coastal mainland Bocas del Toro Province (and possibly into southeastern Costa Rica) and because it exhibits surprisingly high levels of phenotypic variation within and among populations, thereby suggesting that the entire coastal region of northwestern Panama represents a zone of repeated, episodic convergence/hybridization events resulting from regular cycles of rising and falling sea levels. If so, this area represents an extremely important genetic refuge for the plicate-leaved zamias of northwestern Panama.

The plicate-leaved zamias of Bocas del Toro are members of a convoluted, actively evolving species complex that has undergone numerous cycles of geographic isolation and admixture/introgression during inter-glacial periods and ice ages, respectively (Schutzman, 2004; Taylor et al., 2008). The coastal mainland region, which is home to Zamia skinneri, represents the center of diversity of this complex, and Z. hamannii, Z. imperialis, Z. nesophila, and Z. neurophyllidia are incipient species that have evolved allopatrically on the periphery as a result of geographic isolation (in the case of Z. hamanni and Z. nesophila) and/or other as yet unknown abiotic and/or biotic factors (in the case of Z. imperialis and Z. neurophyllidia) perhaps during the current inter-glacial period (Taylor et al., 2012). As such, the 'Skinneri Complex' represents another example (in addition to the Mexican species of Dioon) of rapid evolution in this ancient plant group, effectively countering the assumption of gradual divergence of taxa over evolutionary time that is often ascribed to such long-living organisms.

\section{Phylogeny of isthmian cycads}

All of the described species of isthmian cycads have acquired species status by the usual method of Adansonian discrimination, based on overall similarity of morphologic characteristics considered important. However, newer methods in phylogenetics that combine morphology and molecular data are opening new avenues for understanding speciation in cycads. Morphological and morphometric character sets in cycad identification and systematics should be used with caution, however, because under ex situ conditions (gardens, homes, landscapes), modification of those characters can cause confusion if not 
taken into account and clarified. Conversely, data from morphology and morphometrics, combined with a molecular approach and analyzed using cladistic methods, can define monophyletic groups (clades) of taxa (Schuh and Brower, 2009; Wiley and Lieberman, 2011).

Within the Zamiaceae, Zamia Linnaeus, with 71 currently recognized species (Osborne et al., 2012) distributed from southeastern USA through Central America and the Caribbean to Brazil, is the least-studied genus in terms of phylogenetics. However, there are two previous studies on the phylogeny of Zamia (Caputo et al., 1996; 2004), with the latter using a data matrix that combined molecular data with morphological data. Caputo et al. (2004) demonstrated that Zamia is divided into four major clades, which are also supported by geography (Fig. 12). The backbone of the consensus tree was composed of various species found in Mega-Mexico (see Nicolade-Morejon et al. [2009] for a thorough discussion of Zamia in Mega-Mexico) and is herein referred to as the Mega-Mexico Grade (Fig. 12). While the pattern of phylogenetic relationships uncovered by Caputo et al. (2004) was broadly congruent with geographical distribution, it was not so with morphological resemblance within the genus. An example of the latter is the independent evolution of leaflet "plication" within the genus, as mentioned above and discussed again below.

The current phylogenetic research on Zamia has expanded the sampling of species by $30 \%$, from 23 species in the Caputo et al. (2004) paper to 36 species in this paper. All data were obtained and analyzed exactly as in Caputo et al. (2004), and the results produced one fully resolved tree whose topology has remained the same as the consensus tree of Caputo et al. (2004), including the nesting of Chigua within Zamia (Fig. 12). Not too surprisingly, Lindström (2009) recently synonymized Chigua with Zamia. The phylogenetic and biogeographic implications of this expanded study led to some surprising conclusions as summarized below.

The results of this investigation offer new insights into the phylogeny of Zamia and provide fertile ground for further testing the addition of new species. One of the most surprising results is the relationship of the Panamanian endemic Z. ipetiensis in the Panama Clade with the Colombian endemic Z. wallisii in the South American Clade. These two species show little or no resemblance to each other, other than belonging to the same genus. However, given that Z. manicata is found only in Colombia and the Darién region of Panama-and as such represents a South American element in Colombia-the same may well be true for $Z$. ipetiensis, which, along with Z . cunaria, may represent a relic. This issue should be more rigorously tested by inclusion of the latter in future studies.

Within the Panama Clade (the "pseudoparasitica clade" of Caputo et al. [2004]), there is a subclade of plicate-leaved zamias, consisting of Z. dressleri, Z. neurophyllidia, and Z. skinneri, with Z. obliqua (without plicate leaflets) nested inside. Interestingly, Z. obliqua was taken by Caputo et al. (2004) to be an exception in their inclusive clade of Central American taxa because its distribution was then thought to be extreme eastern Panama to the southern Chocó of Colombia; however, the known range of this species actually extends to at least west-central Panama. As mentioned previously, the presence of plicate leaflets has clearly evolved at least twice within Zamia, and the relationship of plicate leaflets to habitat and other factors is enigmatic, as is the apparent loss of leaflet plication in Z. obliqua.

The distribution of Zamia obliqua also warrants further field work, with more samples taken across its range included in phylogenetic studies. Zamia obliqua has a disjunct distribution from central Panama to the Darién and adjacent Chóco of Colombia and then to Cabo Corrientes, Colombia. At issue here is whether or not Z. obliqua represents a disjunct 




Fig. 12. Resolved tree of the genus Zamia using molecular and morphological data (Caputo et al., 2004; current paper): 1. Caribbean Clade, with the Mexican Z. fischeri as its sister species; 2. South American Clade; 3. Panama Clade; and 4. Mega-Mexico grade.

distribution of a single species or the existence of more than one related species. Regardless if it is one species or a clade of sister species, it appears that Z. obliqua is a Panamanian taxon that also occurs in Colombia. If, however, Z. obliqua represents two species in different clades (i.e., one in the Panama Clade and one in the South America Clade), then the common morphology of plants in the various disjunct localities must have evolved independently in response to similar environmental pressures.

Another interesting disjunct distributional pattern is that of Zamia chigua and Z. lindleyi. These two species are currently recognized as distinct taxa (Osborne et al., 2012) but have been considered conspecific in previous treatments of Zamia for Panama (Stevenson, 1993) and for Colombia (Stevenson, 2001). However, recent work has shown that these do, indeed, represent two distinct species based on morphological features of leaves, cones, and spines (Calonje et al., 2011). These two entities are strikingly disjunct, with Z. chigua known only from the Cabo Corrientes area of the Chóco region of Colombia, and Z. lindleyi known only from a small area of Chiriquí Province in northwestern Panama. Given that these two 
species are obviously very similar morphologically, the question arises whether they are sister species or are each related to species in other clades. Regardless, the ecology and biology of these organisms must be better known to understand why they are so widely disjunct but yet currently so restricted in range.

Some striking aspects concerning the distribution of Zamia in Central America, excluding Mega-Mexico, is the high endemism and morphological diversity in western Panama and adjoining Costa Rica. The Panama Clade contains one of the smallest Zamia species known (Z. acuminata), the only epiphytic cycad (Z. pseudoparasitica), and the majority of the largest trunking species in the genus (Z. hamannii, Z. nesophila, Z. obliqua, and Z. skinneri). Habitats also vary greatly, ranging from high-level cloud forest to sea-level island beaches. The recent elucidation of the variability within the previously described Z. neurophyllidia and Z. skinneri resulted in the recognition of three new distinct species, $Z$. hamannii, $Z$, imperalis, and $Z$. nesophila, all of which are plicate-leaved (Taylor et al., 2008). These discoveries await detailed phylogenetic and ecological analyses, but clearly show adaptations to varied conditions. In contrast to the other plicate-leaved species in Panama that occur primarily in montane forests, Z. nesophila and Z. hamannii are island-dwellers that are exposed to, and often inundated by, seawater. Interestingly, Z. roezlii, which is endemic to the Buenaventura area of the Chóco, Colombia, also has plicate leaves and can live in mangrove swamps.

Finally, it should be noted that Zamia acuminata needs to be better defined, because the originally described species grows along the San Juan River in Nicaragua, and is reportedly morphologically dissimilar to the plants bearing the same (misapplied) name in Panama (Schutzman, 2004; Lindström, pers. comm.).

\section{Conservation efforts \& isthmian cycads}

Cycads in Panama face an ongoing condition of destruction and illegal extraction in almost all natural populations visited. Populations near newly opened highways are readily disposed of, either because the people working nearby do not know the academic or commercial value of the plants or because they become readily available to poachers. On many occasions a few colleagues have addressed the issue, and an international conference on cycad biology took place in Panama City in 2008, in which all delegates signed a public petition for the government of Panama through the auspices of the University of Panama to take under its responsibilities the extension of cycad biology works and conservation and to make the public aware of the problem at issue. However, outside the support of the university for the senior author's basic research on isthmian cycad biology and conservation as a full time research faculty, including minimal support for a fledging ex situ cycad garden, very little has been done to insure the health of cycad populations throughout the isthmus. Furthermore, basic funding for cycad research is lacking.

\subsection{Conservation status of natural forests \& cycad survival}

The Isthmus of Panama has a natural forest surface of approximately 3 million ha (44\% of the land surface), although conditions of climate and soil are adequate for almost all the available land surface to be forested. The loss of forest surface is associated with anthropogenic activities occurring at different times, and deforestation of natural vegetation is a threat to the survival of isthmian cycads because they are almost all understory species. The history of the isthmus shows that deforestation began with the first human settlements, approximately 7 kya (Cooke, 
2003). Since then, destruction of the forests has been continual, with periods of lesser activities. More recently, although the rate of deforestation has been reduced, there is still pressure to use forest land for different types of human activities, such as the establishment of human centers and for the production of foodstuffs. To face this threat of losing natural forests and their biodiversity, a National System of Protected Areas (SINAP for the Spanish acronym for Sistema Nacional de Áreas Protegidas) has been established, which covers 36\% of the land mass of the isthmus. Although there are efforts to preserve forests, the habitat of cycads, there are still natural populations of cycads outside of protected areas. In certain cases, forests outside protected areas still have large populations of cycads, such as Zamia pseudoparasitica, which survives primarily on very high branches of trees in Veraguas, Coclé, and Colón provinces of north-central Panama. Because of this, it is vital to conduct research that points to forests with extant cycad populations for these forests to be included in SINAP.

\subsection{Local conservation initiatives}

The best approach for cycad conservation in Panama is to meet with local people and to form a team, with communication between researchers and locals at fixed intervals. Donating cell phones, in certain areas, and even small digital cameras, can help volunteers locate and relay situations in the field to a center with better infrastructure. At all times, Panamanian National Environmental Authority (ANAM) personnel should be kept abreast of what is being done. Thousands of plants and many populations have been destroyed for road building, creation of pastures for cattle grazing, or just because the plants had no immediate use for the community. ANAM states that there is no money to save cycads. This being the case, the job is left to academic institutions and the private sector. As a result, all of the Panamanian species should have at least the following Red List category rating: Critically Endangered (CR B1, I, iii-v) (IUCN, 2001). Land owners in most provinces with cycads have been approached, and the discussion of conservation has been positive. However, the problem remains quite unsettled (see also Taylor et al., 2007). In fact, many populations that were quite healthy and with sizeable numbers of individuals, are now down to few and scattered plants, and even places in which the owners had given hope of conservation have not been left unscathed, basically because new roads have been opened during the intervening years and new settlements have been made. Populations in northwestern Panama along river embankments are at the moment safe because of the difficulty of getting to those places and the very aggressive attitude of aboriginals in their homelands to defend their environment. Alas, even here, at present, there is danger of deforestation due to the construction of dams and the human use of the surrounding land in which the cycad populations survive.

\section{Conclusion}

Cycads arrived from both South and North America into the Isthmus of Panama, and new species evolved there, the original progenitors having existed globally for over 300 million years and predating the breakup of Pangaea. Today's extant cycads occupy mainly tropical and subtropical regions of the world. Panama supports at least 17 species, making the isthmus a cycad biodiversity hotspot because there are more representatives per unit land mass than in any other region of the neotropics.

Endemism has been the rule, with most cycads in the Isthmus of Panama forming relatively small, endemic populations, and with most populations numbering only a few hundred individuals. Morphological diversity is rampant within the Panamanian cycad flora-from 
those with underground stems to those with huge trunks and a wide range of other divergent characters, such as cone morphology and morphometrics, and leaf type and number. We still cannot answer the question of why cycads have survived so long with relatively similar vegetative and reproductive structures of millions of years ago, but it could be linked to their individual longevity, production of toxic substances, and absence of herbivores as a result of those substances. Cycad survival is challenged by human alteration of habitat, including clearing of forests and converting "cycad land" to roads, development, and cattle ranching, as well as illegal removal of plants for black market sale, which is taking many rare species to the brink of extinction.

We describe cycad distribution and evolution in relation to the origin of the Isthmus of Panama and the Great American Biodiversity Interchange, which was completed beginning about 3 mya (although there were temporary closings and openings of the seaway for millions of years before definite closure), and during which period cycads likely made their way from both the north and the south towards the isthmus. We also summarize our hypothesis for the current biogeography and ongoing evolution of the plicate-leaved 'Skinneri Complex' in northwestern and north-central Panama.

A complete phylogeny is still lacking for the genus Zamia, but what is known provides insight and testable hypotheses into how the genetic makeup of this genus relates to geologic changes and the present-day geographic distribution of the member species. Future work with more species examined and using other genome sets and/or molecular markers will provide a better understanding of this problem, and more species surveys and descriptions are needed to address the question of synonymy of many entities, with Z. cunaria vs. Z. ipetiensis and Z. acuminata in Panama vs. Z. acuminata from Central America being noteworthy examples. More work is also needed in the 'Skinneri Complex', and the arduous work already conducted (Taylor et al., 2008) should be addressed when speaking of Z. skinneri in a general way.

The study of cycad pollination biology in Panama is under way, and the genera (or similar/related genera) of some insect pollinators have been determined. This ongoing work includes a phylogeny of the pollinators as well as descriptions of putative new species. Also, new work will soon begin on heat production in Zamia cones and the volatile emissions that are associated with pollinator activity.

Last but not least, we address the problem of disappearing forests and the clearing of natural populations of Zamia on the isthmus. A great fear is that populations not yet studied will disappear in the immediate future, due to the clearing of land for human use and the inability of the understaffed and inadequate organization of the Natural Environmental Authority of Panama. In this respect, just trying to save what is left of these populations is a great challenge.

\section{Acknowledgment}

We acknowledge the support by the administration of the University of Panama (President, Vice-President for Research and Graduate Studies, and various deans of the Faculty of Natural and Exact Sciences and Technology) of the senior author as full-time research faculty and also for infrastructure where possible (e.g., space for a cycad garden-with over 2,000 plants, including germlings, young plants, and mature, non-coning and coning individuals - to grow native and naturalized species of cycads and a reservoir of specimens for all of the known populations of isthmian cycads, plus representatives of the world cycad flora). Partial financial 
support came from NSF grants (BSR-8607049, EF 0629817, IOS 0421604) to D.W.S. We are also grateful for the partial support of the National Environmental Authority of Panama (ANAM) for granting us permission to carry out research on isthmian cycads in national parks and especially in the homelands of the aboriginal people in almost every province of the republic. The senior author is also indebted to his wife, Isabel Debora Herrera Antaneda, for her moral support during the writing of this paper. Our thanks go to Mr. Eduardo Sánchez, who has been working as a field assistant on the ecology of Zamia elegantssima, and to Dr. Anthony Coates of the Smithsonian Tropical Research Institute in Panama, who provided valuable suggestions and permission to use the maps in Fig. 11.

\section{References}

ANAM. (2006). Indicadores Ambientales de la República de Panamá (Environmental Meters of the Republic of Panama), ANAM, Panamá, Quebecor World Bogotá, S.A., Colombia

Anderson, R.P. \& Handley, Jr., C.O. (2001). A new species of three-toed sloth (Mammalia: Xenarthra) from Panama, with a review of the genus Bradypus. Proceedings of the Biological Society of Washington, Vol. 114, No. 1, (April 2001), pp. 1-33

Anderson, R.P. \& Handley, Jr., C.O. (2002). Dwarfism in insular sloths: Biogeography, selection, and evolutionary rate. Evolution, Vol. 56, No. 5, (May 2002), pp. 1045-1058

Calonje, M.A., Taylor, A.S., Stevenson, D.W., Holzman, G. \& Ramos, Y.A. (2012). Zamia lindleyi: A misunderstood species from the highlands of western Panama, In: Proceedings of the $8^{\text {th }}$ International Conference on Cycad Biology, Panamá, Panamá, January 2-8, 2008, Memoirs of the New York Botanical Garden, Vol. 106, in press

Caputo, P., Cozzolino, S., Gaudio, L., Moretti, A. \& Stevenson, D.W. (1996). Karyology and phylogey of some Meso-American species of Zamia (Zamiaceae). American Journal of Botany, Vol. 83, No. 11, (November 1996), pp. 1513-1520

Caputo, P., Cozzolino, S., De Luca, P., Moretti, A. \& Stevenson, D.W. (2004). Molecular phylogeny of Zamia (Zamiaceae), In: Cycad Classification: Concepts $\mathcal{E}$ Recommendations, Walters, T. \& Osborne, R. (Eds.), pp. 149-157, CABI Publishing, ISBN 0-85199-741-4, Cambridge, MA, USA

Chamberlain, C.J. 1919. The Living Cycads, University of Chicago Press, Chicago, IL, USA

Chamberlain, C.J. 1935. Gymnosperms: Structure \& Evolution, University of Chicago Press, Chicago, IL, USA

Coates, A. (2003). Forja de Centroamérica (The Rise of Central America), In: Una Historia de la Naturaleza y Cultura de Centroamérica: Paseo Pantera, Coates, A. (Ed.), pp. 1-40, Smithsonian Books, Washington, D.C., USA

Coates, A.G., McNeill, D.F., Aubry, M-P., Berggren, A. \& Collins, L.S. (2005). An introduction to the geology of the Bocas del Toro Archipelago, Panama. Caribbean Journal of Science, Vol. 41, No. 3, (2005), pp. 374-391

Coates, A. \& Obando, J. (1996). The geologic evolution of the Central American isthmus, In: Evolution \& Environment in Tropical America, Jackson, J., Budd, A. \& Coates, A. (Eds.), pp. 21-56, University of Chicago Press, Chicago, IL, USA

Cooke, R. (2003). Los pueblos indígenas de Centroamérica durante las épocas precolombinas y colonial, In: Una Historia de la Naturaleza y Cultura de Centroamérica: Paseo Pantera, Coates, A. (Ed.), pp. 153-196, Smithsonian Books, Washington, D.C., USA

Dickau, R.A., Ranere, A.J. \& Cooke, R.G. (2007). Starch grain evidence for the preceramic dispersals of maize root crops into tropical dry and humid forests in Panama. Proceedings of the National Academy of Sciences, Vol. 104, No. 9, (2007), pp. 3651-3656 
Gomez, L.D. (1982). Plantae Mesoamericanae Novae. II. Phytologia, Vol. 50, No. 6, (1982), pp. 401-404

Gregory, T.J. \& Chemnick, J. (2004). Hypotheses on the relationship between biogeography and speciation in Dioon (Zamiaceae), In: Cycad Classification: Concepts $\mathcal{E}$ Recommendations, Walters, T. \& Osborne, R. (Eds.), pp. 137-148, CABI Publishing, ISBN 0-85199-741-4, Cambridge, MA, USA

Instituto Geográfico Nacional Tommy Guardia. (2007). Atlas Nacional de la República de Panamá, Ministerio de Obras Públicas, Panamá, Panamá

IUCN. (2001). IUCN Categories \& Criteria, ver. 3.1, IUCN Species Survival Commission, Gland, Switzerland

Lindström, A.J. (2009). Typification of some species names in Zamia L. (Zamiaceae), with an assessment of the status of Chigua D.W. Stev. Taxon, Vol. 58, No. 1, (February 2009), pp. 265-270

Louis Berger Group. (2000). Mapa de vegetación de Panamá. Corredor Biológico Mesoamericano del Atlántico Panameño, Autoridad Nacional del Ambiente (ANAM), Panamá, Panamá

Louis Berger Group. (2003). Informe: Recopilación y Presentación de Datos Ambientales y Culturales en la Región Occidental de la Cuenca del Canal de Panamá, Louis Berger Group, Inc., Panamá, Panamá

Janzen, D.H. (1981a). Guanacaste tree seed-swallowing by Costa Rican range horses. Ecology, Vol. 62, No. 3, (June, 1981), pp. 587-592

Janzen, D.H. (1981b). Enterolobium cyclocarpum seed passage rate and survival in horses, Costa Rican Pleistocene seed dispersal agents. Ecology, Vol. 62, No. 3 (June, 1981), pp. 593-601

Jones, D.L. (2002). Cycads of the World. Ancient Plants in Today's Landscape (2nd edition), Smithsonian Institution Press, ISBN 1-58834-043-0, Washington, D.C., USA

Nicolade-Morejón, F., Vovides, A.P. \& Stevenson, D.W. (2009). Taxonomic revision of Zamia in Mega-Mexico, Brittonia, Vol. 61, (2009), pp. 1-38

Norstog, K.J. \& Nicholls, T.J. (1997). The Biology of the Cycads, Cornell University Press, ISBN 0-8014-3033-X, Ithaca, NY, USA

Osborne, R., Stevenson, D., Hill, K. \& Stanberg, L. (2012). The World List of Cycads/La Lista Mundial de Cícadas, In: Proceedings of the $8^{\text {th }}$ International Conference on Cycad Biology, Panamá, Panamá, January 2-8, 2008, Memoirs of the New York Botanical Garden, Vol. 106, in press

Pearson, H.H.W. (1906). Note on the South African cycads. I. Transactions of the South African Philosophical Society, Vol. 16, (1906), pp. 341-354

Pott, C., McLaughlin, S. \& Lindström, A. (2010). Late Palaeozoic foliage from China displays affinities to Cycadales rather than to Bennetitales necessitating a re-evaluation of the Palaeozoic Pterophyllum species. Acta Palaeontologica Polonica, Vol. 55, No. 1, (2010), pp. 157-168

Proches, W. \& Johnson, S. (2009). Beetle pollination of the fruit-scented cones of the South African cycad Stangeria eriopus, American Journal of Botany, Vol. 96, No. 9, (2009), pp. 1722-1730

Rattray, G. (1913). Notes on the pollination of some South African cycads, Transactions of the Royal Society of South Africa, Vol. 3, (1913), pp. 259-270

Schuh, R. \& Brower, A. (2009). Biological Systematics: Principles \& Applications (2nd edition), Cornell University Press, ISBN 978-0-8014-4799-0, Ithaca, NY, USA

Schutzman, B. (2004). Systematics of Meso-American Zamia (Zamiaceae), In: Cycad Classification: Concepts \& Recommendations, Walters, T. \& Osborne, R. (Eds.), pp. 159172, CABI Publishing, ISBN 0-85199-741-4, Cambridge, MA, USA

Schutzman, B., Vovides, A.P. \& Adams, R.S. (1998). A new Zamia (Zamiaceae, Cycadales) from central Panama. Phytologia, Vol. 85, No. 3, (September 1998), pp. 137-145 
Stevenson, D.W. (1993). The Zamiaceae in Panama with comments on phytogeography and species relationships, Brittonia, Vol. 45, No. 1, (March 4, 1993), pp. 1-16

Stevenson, D.W., Norstog, K.J. \& Fawcet, P.K.S. (1998). Pollination biology of cycads, In: Reproductive Biology, Owens, S.J. \& Rudall, P.J. (Eds.), pp. 277-324, Royal Botanic Gardens, Kew, UK

Stevenson, D.W. (2001). Cycadales, In: Flora de Colombia, Bernal, R. \& Forero, E., (Eds.), pp. 192, Instituto de Ciencias Naturales, Universidad Nacional de Colombia, ISSN 01204351, Bogotá, Colombia

Suinyuy, T.N., Donaldson, J.S. \& Johnson, S.T. (2012). Role of cycad cone volatile emissions and thermogenesis in the pollination of Encephalartos villosus Lehm: Preliminary findings from studies of plant traits and insect responses, In: Proceedings of the $8^{\text {th }}$ International Conference on Cycad Biology, Panamá, Panamá, January 2-8, 2008, Memoirs of the New York Botanical Garden, Vol. 106, in press

Taylor, A.S. (1999). Natural reproductive population structure and pollination in Panamanian Zamia. Abstract, XVI International Botanical Congress, St. Louis, MO, USA

Taylor, A.S. (2002). Irrefutable proof of insect pollination in Zamia elegantissima Schutzman, Vovides \& Adams, In: Proceedings of the International Conference on Tropical Ecosystems Tropical Forests: Past, Present \& Future (Association for Tropical Biology Annual Meeting \& Smithsonian Tropical Research Institute), Panamá, Panamá, July 30August 2, 2002

Taylor, A.S., Haynes, J.L. \& Holzman, G. (2008). Taxonomical, nomenclatural, and biogeographical revelations in the Zamia skinneri species complex (Cycadales: Zamiaceae) of Central America, Botanical Journal of the Linnean Society, Vol. 158, (2008), pp. 399-429

Taylor, A.S., Haynes, J.L. \& Holzman, G. (2012). The Zamia skinneri (Cycadales: Zamiaceae) complex in Panama, In: Proceedings of the $8^{\text {th }}$ International Conference on Cycad Biology, Panamá, Panamá, January 2-8, 2008, Memoirs of the New York Botanical Garden, Vol. 106, in press

Taylor, A.S., Haynes, J.L., Holzman, G. \& Mendieta, J. (2007). Variability of natural populations and conservation issues facing plicate-leaved Zamia species in Central America, In: Proceedings of the $7^{\text {th }}$ International Conference on Cycad Biology, pp. 557-577, ISSN 0077-8931, Xalapa, Mexico, January 8-12, 2005, Memoirs of the New York Botanical Garden, Vol. 97, pp. 557-577

Taylor, A.S. (2012). Notes on the ethnobotany of Panamanian cycads, In: Proceedings of the $8^{\text {th }}$ International Conference on Cycad Biology, Panamá, Panamá, January 2-8, 2008, Memoirs of the New York Botanical Garden, Vol. 106, in press

Terry, I., Walter, G., Moore, C., Roemer, R. \& Hull, C. (2007). Odor-mediated push-pull pollination in cycads, Science, Vol. 318, (2007), p. 70

Webb, D.S. (1997). The great American faunal interchange, In: Central America, a Natural and Cultural History, Coates, A.G. (Ed.), pp. 97-122, Yale University Press, New Haven, CT, USA

Wikipedia. (2011). Panamá, Wikipedia La Encyclopedia Libre, 5 December 2011, Available from <http://es.wikipedia.org/wiki/Panama>

Wikipedia. (2012). Geography of Panamá, Wikipedia, 7 January 2012, Available from $<$ http://en.wikipedia.org/wiki/Geography_of_Panama>

Wiley, E.O. \& Lieberman, B.S. (2011). Phylogenetics: The Theory of Phylogenetic Systematics (2nd edition), Wiley-Blackwell, 978-0-470-90596-8, Hoboken, NJ, USA

Wilson, G. (2002). Insect pollination in the cycad genus Bowenia Hook ex Hook. f. (Stangeriaceae), Biotropica, Vol. 34, No. 3 (September, 2002), pp. 438-441 


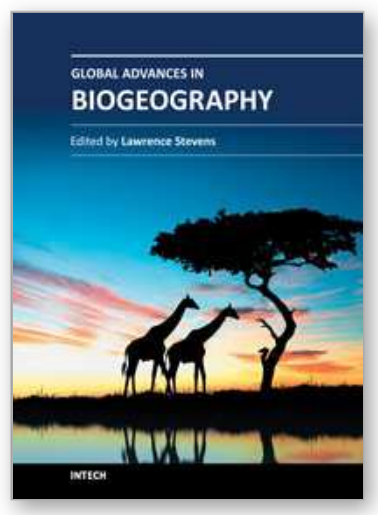

\author{
Global Advances in Biogeography \\ Edited by Dr. Lawrence Stevens
}

ISBN 978-953-51-0454-4

Hard cover, 360 pages

Publisher InTech

Published online 30, March, 2012

Published in print edition March, 2012

Global Advances in Biogeography brings together the work of more than 30 scientific authorities on biogeography from around the world. The book focuses on spatial and temporal variation of biological assemblages in relation to landscape complexity and environmental change. Global Advances embraces four themes: biogeographic theory and tests of concepts, the regional biogeography of individual taxa, the biogeography of complex landscapes, and the deep-time evolutionary biogeography of macrotaxa. In addition, the book provides a trove of new information about unusual landscapes, the natural history of a wide array of poorly known plant and animal species, and global conservation issues. This book is well illustrated with numerous maps, graphics, and photographs, and contains much new basic biogeographical information that is not available elsewhere. It will serve as an invaluable reference for professionals and members of the public interested in global biogeography, evolution, taxonomy, and conservation.

\title{
How to reference
}

In order to correctly reference this scholarly work, feel free to copy and paste the following:

Alberto S. Taylor B., Jody L. Haynes, Dennis W. Stevenson, Gregory Holzman and Jorge Mendieta (2012). Biogeographic Insights in Central American Cycad Biology, Global Advances in Biogeography, Dr. Lawrence Stevens (Ed.), ISBN: 978-953-51-0454-4, InTech, Available from: http://www.intechopen.com/books/globaladvances-in-biogeography/biogeographic-insights-in-central-american-cycad-biology

\section{INTECH}

open science | open minds

\author{
InTech Europe \\ University Campus STeP Ri \\ Slavka Krautzeka 83/A \\ 51000 Rijeka, Croatia \\ Phone: +385 (51) 770447 \\ Fax: +385 (51) 686166 \\ www.intechopen.com
}

\author{
InTech China \\ Unit 405, Office Block, Hotel Equatorial Shanghai \\ No.65, Yan An Road (West), Shanghai, 200040, China \\ 中国上海市延安西路65号上海国际贵都大饭店办公楼405单元 \\ Phone: +86-21-62489820 \\ Fax: +86-21-62489821
}


(C) 2012 The Author(s). Licensee IntechOpen. This is an open access article distributed under the terms of the Creative Commons Attribution 3.0 License, which permits unrestricted use, distribution, and reproduction in any medium, provided the original work is properly cited. 